\title{
UTILIZING UNIVERSITY AND STUDENT DIGITAL DEVICES FOR TEACHING AND LEARNING
}

\author{
Sylvia A. Bembry, Winston-Salem State University, bembrys@wssu.edu \\ Carolyn Anderson, Winston-Salem State University, andersonc@wssu.edu \\ La-Donia Alford Jeffries, alfordlj@gmail.com
}

\begin{abstract}
This study is two-fold. First, students constantly use digital devices during class. Learning how to coordinate university assignments with digital devices used by students is essential. Second, what do professors need to change in teaching methodology to better engage the students with meaningful experiences while using digital devices brought to class? The idea was to use other methods of teaching/facilitating where students could utilize the digital devices in class. Digital device usage in the classroom is a method tried for two freshmen level courses.
\end{abstract}

Keyword: Digital Device, Teaching, Learning and Social Media

\section{INTRODUCTION}

Digital device such as smartphones, tablets, and netbooks, now permeate our society. Initially, these tools were used for collaborating, scheduling, and authoring on a personal level. Today, however, courses can be redesigned where digital devices are used for university teaching and learning. It is important to adapt to technology with use of digital devices because the "net generation" utilizes multiple devices for conversations, rather than a lecture; instead of reading a book students may prefer eBooks. Also, students might skip around the page scanning for pertinent information of interest. It is time to take the challenge of changing from lecture and printed books and use what the population wants - digital devices.

\section{LITERATURE REVIEW}

Pros and cons about digital devices in education are reported in the literature. Some digital devices will be explained to show how social media tools are applied to teaching and learning. With digital devices, out-of-class learning was combined with traditional face-to-face instruction to create a positive experience. Shih states that out-of-class learning through digital devices has become increasingly important and critical for education [8].

Models and makes of laptops used in classrooms varied. Students stated laptops are used for communicating, storing documents, research, and note taking. Sometimes students email during class to professors and friends. Instant messaging and video-conferencing are often used for group assignments for students not in that particular section or class [1].

One of the newest devices is the iPad. Two executive programs in the MBA program deliver all required books and case studies digitally with school-purchased iPads [4]. The school partnered with the bookstore to switch to digital materials from print. At another university, students are required to have a tablet. Professors ask questions and students often organize groups and write answers that are shared [3].

The cell phone is another popular digital device. This device offers professors a way to engage students in learning that translates to real world situations and the possibilities are endless. It is often times difficult to keep pace with changing devices because of budgetary restrictions; but the professors can find ways to integrate new devices into classroom instruction. Students are utilizing devices to enhance critical thinking and problem solving techniques. 
Sometimes students want to just listen to music and may enjoy the convenience of lestening to discussions on their devices. IPods are used for this kind of entertainment and to review materials from class. .Some students like soothing music to take tests and complete projects.

\section{DIGITAL DEVICES USED FOR TEACHING AND LEARNING}

Digital devices `consist of many pieces of technology that are required in everyday use.

$\underline{\mathrm{iPad}}$

The iPad is a relatively new technological device manufactured by Apple, Inc. Since its debut, professors in many parts of the world have been looking for new ways to incorporate it into learning, both inside and outside of the classroom. Apple, along with other software manufacturers, has come up with applications to further learning across the board.

$\underline{\text { SmartPhone }}$

A second device, smartphones, plays a key part in activities like notifying students when to wake up and head to class and other appointments and also help keep in close contact and networking with other individuals and large groups of people.

$\underline{\text { iPod }}$

Third, iPods might be the most important of all gadgets because of what it holds within it. With music students would be able to make it through the day in a smooth manner. It serves as both a stimulant and a depressant when needed and allows studenst to relax or get in the right mindset for certain events.

Laptop

Fourth, laptops are always needed in college because there is always a paper to write or research that needs to be looked up. But, what happens when the student who needs to use the computer isn't on campus? Being able to check out a laptop from the university and go where ever you need to go to do your research is always a great thing. Many people work best in different environments and being able to check out laptops is always a help. . Laptops also hold a significant position in both college and personal lives of students. With it a large portion of assignments are completed and the outcome is a good grade.

While these are only four digital devices, there are many more devices at WSSU that can be used for teaching and learning. Digital devices are a part of today's society and will continue to grow as we progress as human beings.

\section{USEFUL APPS ON DIGITAL DEVICES}

Apps can be downloaded to digital devices. The iPad device, for example, plays an essential role in education and should continue to be incorporated into the classroom and beyond. These are a few apps that puts students in control of and responsible for their own education. Social media tools, including Twitter, Facebook, Goggle+, Instagram, and YouTube are changing the way students and faculty communicate, share ideas, and build networks. As with many other technologies, educational communities have harnessed the potential of these resources to improve teaching and learning.

Facebook can be considered a more advanced interactive site where there is discussion or message board and for uploading pictures and videos. Students can access the site freely with digital devices to share information and knowledge, interact, and communicate with others. Twitter is another pedagogical tool for teaching and learning. 


\section{Issues in Information Systems}

Volume 14, Issue 2, pp.34-38, 2013

Twitter is a tool that enhances interaction in a course throughout the classroom that can have strong instructional value for each student. Learning by doing fits well with digital devices.

One important app in education is the Blackboard learning app. This program lets students involved in college level courses view, edit, and submit assignments on-the-go. Not only is this app a benefit to busy students, but also to professors as well. Professors are now able to post assignments and grade them without the hassle of sitting behind a desktop computer. The Blackboard app is just one of many applications that have made education simpler through the use of the iPad.

Another helpful app, although exclusive to Winston-Salem State University, is the C.G. O'Kelly Library app. This program makes the library virtual and at the immediate service of students and professors. Through this app, students can search the library catalog, search online databases, and even send text messages to the library staff for tips and general information.

Other iPad applications that are essential to students are the Cloud On and E-Print apps. The Cloud On app is relatively new to Apple and the iPad system. Cloud On works as Microsoft Office on the iPad device. It allows students to create, edit, save, and send Microsoft Word documents, PowerPoint presentations and Excel spreadsheets. The next app is the E-Print app. This program lets students print on-the-go from any network/Bluetooth compatible printer. Gone are the age-old excuses of printers breaking down and running out of ink. This is just one more of many ways that the iPad puts students in control of and responsible for their own education. Devices such as the Apple iPad play an essential role in education and should continue to be incorporated into the classroom and beyond.

Dropbox, windows live (SkyDrive) and carbonite are used for teaching and learning. Assignments are stored in the dropbox and windows live eliminating the need for printing. Documents can be accessed in the cloud 24/7 by the professor and students for grading and revision. The iPad, digital device, has been a successful tool in making information more readily available to students and professors.

\section{UNIVERSITY FACILITIES HOUSING DIGITAL DEVICES}

The university has facilities where digital devices can be checked out and used by those students who do not have the digital devices needed in class. The library and Video Classroom Technology are two facilities that house old and new technologies. Laptop, iPads, and iPods are available for check out to make presentations, look up information for a research project or paper or even for recreational purposes like uploading videos or watching movies. Cameras are used for taking pictures to include in a personal or professional presentation. Tri-pods to hold the camera are checked out from the university. Memory cards hold all of the footage because a camera's storage sometimes does not have enough storage. Camcorders are available to record video footage for a presentation, an interview or maybe even a personal video to upload to YouTube.

\section{RESEARCH METHOD}

This study original started as an investigation of iPad use in the classroom by the professor. Information Technology installed the hardware needed to use the iPad in classrooms. Only a few students had an iPad, but other students wanted to use whatever devices they had available. More and more students attempted to use other devices during class so there was a mixture of devices being used in the classroom. This caused an influx of numerous questions about how to operate all devices with assignments and the time left to deal with learning course content was minimal.

The next idea was to study the use of multiple digital devices used in the class room. Various versions and makes of smartphones, iPhones, iPods, laptops, and iPads were brought in the classroom. It was then that the decision was made to construct a survey instrument that would capture exactly what students were bringing to college and wanted to use in class. Freshmen level courses, with several sections, were observed for a few weeks to decide on the items 
needed to gather data from students in these sections and other students on campus. The survey instrument contained 15 items regarding digital devices and demographic data. Five hundred and sixteen surveys were collected.

Because 100 percent of students did not have digital devices nor did they have the same digital devices, a search was made to see what digital devices were available at the University for check out by students. Some day's students meet in the assigned classroom and other class periods students met in the library and video classroom technology office where digital devices are located. Each assignment was organized around a theme and students completed assignments using university and personal digital devices.

\section{SURVEY RESULTS}

Students completed five hundred sixteen surveys at the university and the report follows. As exhibited in Table 1, gender of students is almost evenly distributed for those completing the survey. Females accounted for 284 or 55 percent of the 516 total students. Males completing the survey were 232 or 45 percent.

TABLE 1: STUDENT GENDER

\begin{tabular}{|c|c|c|}
\hline & STUDENT GENDER & \\
\hline & NUM BER & PERCENT \\
\hline MALE & 232 & 45 \\
\hline FEMALE & 284 & 55 \\
\hline TOTAL & 516 & 100 \\
\hline
\end{tabular}

Table 2 shows the four university classifications of students. Students were spread over the undergraduate classifications of freshmen, sophomores, juniors, and seniors. More sophomores completed the survey with 185 students or 35 percent. Freshmen represented the second higher number with 129 students or 25 percent. Juniors came in third with 122 students or 24 percent. Seniors were the lowest participants with 80 students and 16 percent.

TABLE 2: STUDENT CLASSIFICATION

\begin{tabular}{|c|c|c|}
\hline & STUDENT CLASSIFICATION & \\
\hline & NUMBER & PERCENT \\
\hline & 129 & 25 \\
\hline FRESHMEN & 185 & 35 \\
\hline SOPHOMORE & 122 & 24 \\
\hline JUNIORS & 80 & 16 \\
\hline SENIORS & 516 & 100 \\
\hline
\end{tabular}

Email, Facebook, and Twitter lead the list for which students use digital devices as shown in Table 3. Only seven students are not using those three social media. For teaching and learning, Blackboard leads as the Apps being used by students. Three hundred and three students use some form of digital device in the classroom.

TABLE 3: REASONS STUDENTS USE DIGITAL DEVICES

\begin{tabular}{|c|c|c|c|c|}
\hline ACTIVITY & NUMBER USING & PERCENT USING & $\begin{array}{c}\text { NUMBER NOT } \\
\text { USING }\end{array}$ & $\begin{array}{c}\text { PERCENT NOT } \\
\text { USING }\end{array}$ \\
\hline E-mail & 516 & 100 & 0 & 0 \\
\hline Facebook & 513 & 99 & 3 & 1 \\
\hline Twitter & 512 & 99 & 4 & 1 \\
\hline Blackboard & 480 & 93 & 36 & 7 \\
\hline Classroom & 303 & 59 & 113 & 21 \\
\hline
\end{tabular}




\begin{tabular}{|c|c|c|c|c|}
\hline Skype & 290 & 56 & 126 & 24 \\
\hline Bing.com & 262 & 51 & 154 & 29 \\
\hline Digital Reader & 199 & 39 & 217 & 42 \\
\hline Newsfeed & 176 & 34 & 240 & 46 \\
\hline
\end{tabular}

\section{CHANGES IN TEACHING METHODOLOGY}

The textbook for the course was available as an eBook and relevant pages were displayed in class using the teacher's iPad. Also the teacher was able to get instant feedback on whether a class understood a concept using Poll Anywhere. Difficult or challenging skills were explained by use of videos that students could play as many times as needed. Elements of the flipped classroom were used for skills that in the past students had found difficult.

\section{CONCLUSIONS}

Students are forcing professors to change teaching/facilitating methods and strategies. The net generation should be allowed to use the digital devices that they are accustomed to using in their daily lives.

\section{REFERENCES}

1. Annan-Coultas, Dustin L., "Laptops as Instructional Tools: Student Perceptions", TechTrends, September/October 2010, Vol. 56, Number 5, p. 34-41.

2. Brady, John, "New Technology: Old Problems in the Classroom", The New England Journal of Higher Education, Summer 2008, p. 5.

3. Costa, Sr., Jonathan P., "Digital Learning for All, Now", Education Digest, April 2013, Vol. 78 Issue 8, p. 4-9.

4. Editor, Exec Ed Goes Digital, BizEd, July/August, 2012, p. 56.Larson, Mark, "Tablets Bring an Interactive Dimension to Classroom Teaching”, San Diego Business Journal, August 16, 2010, p. 24.

5. Mouza, Chrystalla, "Learning with Laptops: Implementation and Outcomes in an Urban, Under-Privileged School, Journal of Research on Technology in Education, Vol. 40 Issue 4, p. 447-472.

6. Rinaldo, Shannon B., Suzanne Tapp, Debra A. Laverie, Learning by Tweeting: Using Twitter as a Pedagogical Tool", Journal of Marketing Education, 2011, 33:193-403.

7. Rinaldo, Shannon B., Suzanne Tapp and Debra A. Laveia, "Learning by Tweeting: Using Martineau, Pamela, “Teaching with Technology", Education Digest, March 2009, Vol. 74 Issue 7, p. 14-18.

8. Shih, Ru-Chu, "Effect of Using Facebook to Assist English for Business Communication Course Instruction", The Turkish Online Journal of Educational Technology, January 2013, Vol. 12, Issue 1, p. 52-59

9. Tomassini, Jason, "Educators Weigh E-Textbook Cost Comparison", Education Week, 5/9/2012, Vol. 31 Issue 30, p. 1-19. 